\title{
Ergonomic workstations for handicraft product made from fluorescent lamp waste
}

\author{
Mochammad Rofieq ${ }^{1, *}$ \\ ${ }^{1}$ Department of Industrial Engineering, University of Merdeka Malang, 65143 Malang, Indonesia
}

\begin{abstract}
One of Micro and Small Enterprises (MSEs) which engages in the field of handicraft in Randuagung Singosari Malang produces various kind of souvenirs, such as twist glass, bell, fruit shaped glass, and wedding souvenirs. All of which are made from fluorescent lamp waste. The waste utilization has become a solution to the overflowing fluorescent waste from factories around the region. As the main factor in determining productivity, workstation is not yet getting serious attention. Workers use short seats when performing work on the handicraft. The tools they use are in lower setting, making them sit in squat-like position. This position setting and the unergonomic workstation tend to make workers feel tired easily which result to the lack productivity. Therefore an ergonomic workstation model is created through the production of fluorescent lamp waste recycling tool with the anthropometric approach. This study used quantitative research method by designing the model based on the anthropometry of the worker's body, resulting in an ergonomic workstation. The resulting model can improve work productivity, which ultimately can improve welfare in a sustainable manner. The application of ergonomic workstation accelerate souvenir making process. Before the design of workstation is 2.58 minute/piece, after the design of workstation is 2.17 minute/piece.
\end{abstract}

\section{Introduction}

In the constitution of the Republic of Indonesia No. 20 / 2008 stated that Micro Enterprises are productive businesses owned by individuals or individual business entities that meet the criteria of micro business as regulated in this constitution. Small Enterprises is a standalone productive economic enterprise, conducted by an individual or business entity that is not a branch of a company owned, controlled, or a part, directly or indirectly, of a medium or large-scale business.

According to the Central Bureau of Statistics, Small Enterprises is a business entity that has a workforce of 5 to 19 people. According to Bank Indonesia, MSE is a company or industry with the characteristics of: capital less than 20 million rupiah; one round of his effort requires only 5 million rupiah; has a maximum asset of 600 million rupiah outside land and buildings; and its annual turnover is less than 1 billion rupiah. Meanwhile, according to the World Bank, MSEs are businesses with a total workforce of \pm 30 people, annual revenues of US \$ 3 million and total assets less than US \$ 3 million.

\footnotetext{
* Corresponding author: mochammad.rofieq@unmer.ac.id
} 
Handicrafts can be defined as products which are produced either completely by hand or with the help of tools. Mechanical tools may be used as long as the direct manual contribution of the artisan remains the most substantial component of the finished product. Handicrafts are made from raw materials and can be produced in unlimited numbers. Such products can be utilitarian, aesthetic, artistic, creative, culturally attached, decorative, functional, traditional, religiously and socially symbolic and significant. (UNESCO/ITC International Symposium on "Crafts and the International Market: Trade and Customs Codification”, Manila, Philippines, October 1997).

Waste is discharged from a production process both industrial and household. Used goods can be a disaster, can also be a blessing if managed properly. In addition to providing financial benefits, the management of used goods also affect the cleanliness of the environment (Suprapto, et al: 2017). For MSEs, the manufacture of handicraft made from waste products is very useful because the crafters can create various design alternatives for the product, so the product look more varied, eye catching, but still maintained its quality (Rofieq, et.al .: 2017).

MSEs in Randuagung Singosari Malang is a home industry which use fluorescent lamp waste from the factories to be recycled as the material to make souvenirs. In the making, it will be processed five times: fluorescent lamp cutting process (to remove the aluminium tip), washing process (to remove the white powder), combustion process (to form the material), water filling process, and sealing process using hot melt adhesive.

Worker performance which is the main factor in determining work productivity is unnoticed. Reviewing the working method aspect, workers use short seats which make them sit in squat-like position. It is caused by the setting of the tool which is lower than the seats. Uncomfortable working position combined with unergonomic workstation make workers tired easily.

Based on the observation, the lack of productivity is caused by inefficient process which require manual air compressor pump. For this reason, a new model of ergonomic workstation through the designing of fluorescent lamp waste recycling tool using the worker's anthropometric measurement is necessary. The design will also consider the workers' limit and ability in interacting with their work environment.

The problems that need to be solved are how to design an ergonomic souvenir making workstation model; how to design better fluorescent lamp waste recycling tool with the respect to the anthropometry aspects; how to discover the standard time using the method of stop watch time study; how to improve the working system of fluorescent lamp waste processing process so that the worker can work effectively, safely, comfortably, and efficiently as well as how to improve work productivity.

\section{Methods}

The data was collected at MSEs which engaged in souvenir making at Randuagung Singosari Malang. Data collection include: specification of MSEs which engaged in the field of handicrafts in Singosari, the availability of raw materials in the form of fluorescent lamp waste, the quality and price of raw materials, the storage of raw materials, the variety of glass souvenir design, burning process and material formation, workstation layout that has been used, liquid filling process (finishing) and the storage of finished products.

\subsection{Anthropometry Modeling}

After obtaining the anthropometry data of worker's body, preparation and model testing is done in Ergonomics Laboratory of University of Merdeka Malang to ensure the relation 
between the physical aspect of the human body with the work device and its environment. This test is conducted with the aim that the new workstation can be used significantly in accordance to the worker's body dimension, so that the worker can perform his job comfortably, effectively and have high productivity.

\subsection{New Workstation Design}

Based on the anthropometry data and the real demand on the process of souvenir making, a new workstation that takes into account the physiological aspects of the worker is designed. This new workstation represents the whole series of souvenir making process, which simulation is done in Laboratory of Measurement and Work Method of University of Merdeka Malang.

\section{Result and Discussion}

Using the Westinghouse system was obtained performance rating for the first operator 1.09; second operator 1.13; and third operator 1.06. Normal Time for the first operator 0.0373 hours; second operator 0.0385 hours; and third operator 0.0363 hours. To determine the percentage of allowance on souvenir making, basic consideration is used, personal requirement $2.50 \%$, recess $4.16 \%$, and delay $6.25 \%$, obtained the total percentage of allowance time of $12.91 \%$.

After the calculation Standard Time is obtained, for the first operator 0.043 hours/piece, second operator 0.044 hours/piece, and the third operator 0.042 hours/piece. Thus, the approximate standard time required by the operator to finish a piece of souvenir in the previous workstation is 0.043 hours/piece or 2.58 minutes/piece.

\subsection{Anthropometry Modeling}

\subsubsection{Table height}

Body dimension that is used in determining the table height is:

the lowest popliteal height (inner knee height) + elbow rest height (elbow height in sitting position) + Allowance (footwear) = table height

$(44+22+2,5) \mathrm{cm}=68,5 \mathrm{~cm}$.

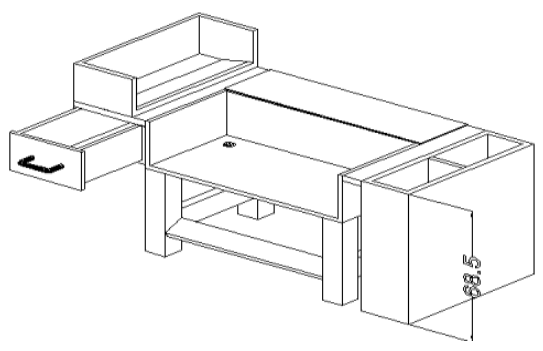

Fig. 1. Workbench height. 


\subsubsection{Table width}

a) Length

Body dimension that is used in determining the table lenght is:

2 times smallest side arm reach $($ side reach $)+$ gloves allowance $=$ table length

$(2 \times 85+0,6) \mathrm{cm}=170,6 \mathrm{~cm}$.

b) Table width

Body dimension that is used in determining the table widht is :

The smallest thumb tip reach $($ fore reach $)+$ gloves allowance $=$ table widht $(76+0,6) \mathrm{cm}=76,6 \mathrm{~cm}$.

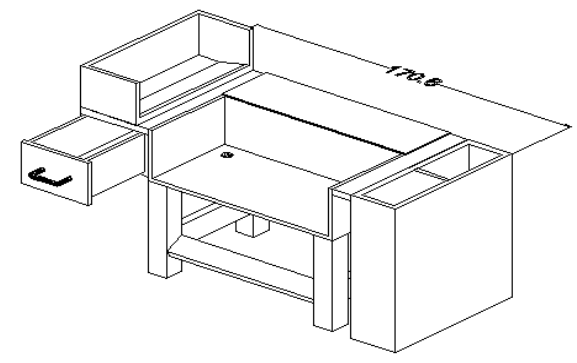

Fig. 2. Workbench length.

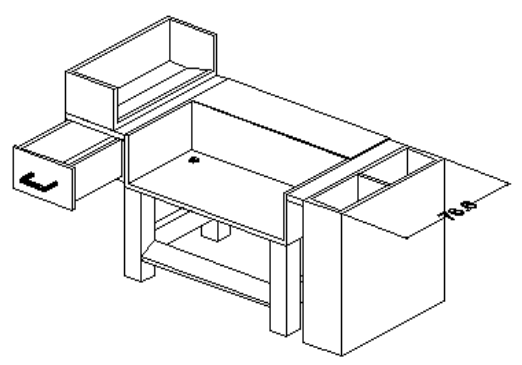

Fig. 3. Workbench width.

\subsubsection{Seat height}

Body dimension that is used in determining the seat height is:

The lowest popliteal height (inner knee height) + footwear allowance = seat height (4) $(44+2,5) \mathrm{cm}=46,5 \mathrm{~cm}$.

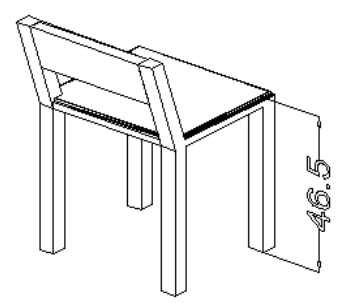

Fig. 4. Seat height. 


\subsubsection{Seat cushion}

a) Seat cushion width

Body dimension that is used in determining the seat cushion width is:

The biggest hip breadth + cloth $=$ seat cushion width

$(42+1,3) \mathrm{cm}=43,3 \mathrm{~cm}$.

b) Seat cushion depth

Body dimension that is used in determining the seat cushion depth is :

The shortest buttockpopliteal length (thigh length) + cloth $=$ seat cushion depth $(48+1,3) \mathrm{cm}=49,3 \mathrm{~cm}$.

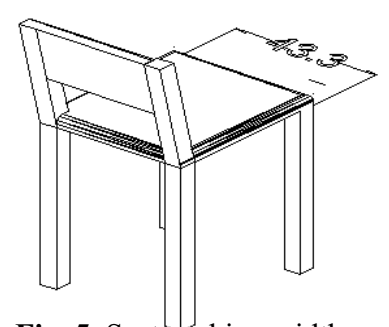

Fig. 5. Seat cushion width.

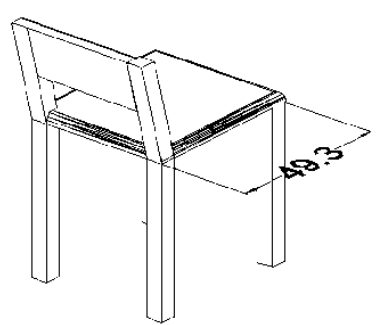

Fig. 6. Seat cushion depth.

\subsubsection{Lumbar backrest height}

Body dimension that is used in determining the lumbar backrest height is:

The lowest lumbar height + cloth allowance $=$ lumbar backrest height $(28,7+1,3) \mathrm{cm}=30 \mathrm{~cm}$.

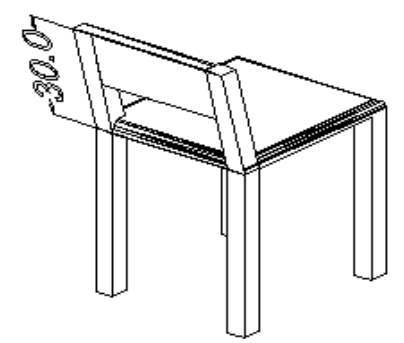

Fig. 7. Lumbar backrest height. 


\subsection{Operator requirement identification}

Table 1. Operator requirement identification.

\begin{tabular}{ll}
\hline \multicolumn{1}{c}{ Question } & \multicolumn{1}{c}{ Operator Statement } \\
\hline Workstation Use & 1. Workstation is required to simplify thework \\
\hline $\begin{array}{l}\text { Preferred things on the } \\
\text { previous workstation }\end{array}$ & 1. Prefered because the stove is easy to turn on \\
\hline $\begin{array}{l}\text { Unpreffered things on the } \\
\text { previous workstation }\end{array}$ & $\begin{array}{l}\text { 1. Not preffered because it needs fuel tube pumping to } \\
\text { increase the air pressure } \\
\text { 2. Workbench and seat are not comfortable } \\
\text { 3. The materials is not reachable } \\
\text { 4. Not enough space to store half-finished product and } \\
\text { finished product }\end{array}$ \\
\hline Improvement Suggestion & $\begin{array}{l}\text { 1. How to reach raw material easier } \\
\text { 2. How to add air pressure withoutleaving the workbench }\end{array}$ \\
& 3. How to work comfortably \\
\hline
\end{tabular}

Table 2. Interpretation of operator requirement.

\begin{tabular}{|c|c|}
\hline Operator Statement & Requirement Statement \\
\hline \multicolumn{2}{|l|}{ Specific use : } \\
\hline $\begin{array}{l}\text { Workstation is required to } \\
\text { simplify the work }\end{array}$ & Tables and seats for souvenir forming and combustion \\
\hline \multicolumn{2}{|c|}{ The advantage of the previous workstation : } \\
\hline It is easy to turn on the stove & The stove is easy to turn on \\
\hline \multicolumn{2}{|c|}{ The disadvantage the previous workstation : } \\
\hline $\begin{array}{l}\text { It needs more time to add air } \\
\text { pressure on the fuel tube }\end{array}$ & Efective tool for air pressure addition \\
\hline $\begin{array}{l}\text { Workbench and seat are not } \\
\text { comfortable }\end{array}$ & Comfortable workbench and seat \\
\hline The materials is not reachable & Reachable materals \\
\hline $\begin{array}{l}\text { No space to put the half-finished } \\
\text { product }\end{array}$ & Space for the half-finished product \\
\hline $\begin{array}{l}\text { No space to store finished } \\
\text { product }\end{array}$ & Space to store finished product \\
\hline \multicolumn{2}{|l|}{ Improvement Suggestion : } \\
\hline $\begin{array}{l}\text { Space to store raw material, half- } \\
\text { finished procuct, and finished } \\
\text { product }\end{array}$ & $\begin{array}{l}\text { Workbench with enough space to store raw material, half- } \\
\text { finished procuct, and finished product }\end{array}$ \\
\hline $\begin{array}{l}\text { Less time for fuel tube air } \\
\text { pressure addition }\end{array}$ & Equipped with compressor to add air pressure \\
\hline Comfortable workbench and seat & $\begin{array}{l}\text { Workbench and seat have to be made based on operator } \\
\text { anthropometric measurement }\end{array}$ \\
\hline
\end{tabular}




\subsection{New workstation design}

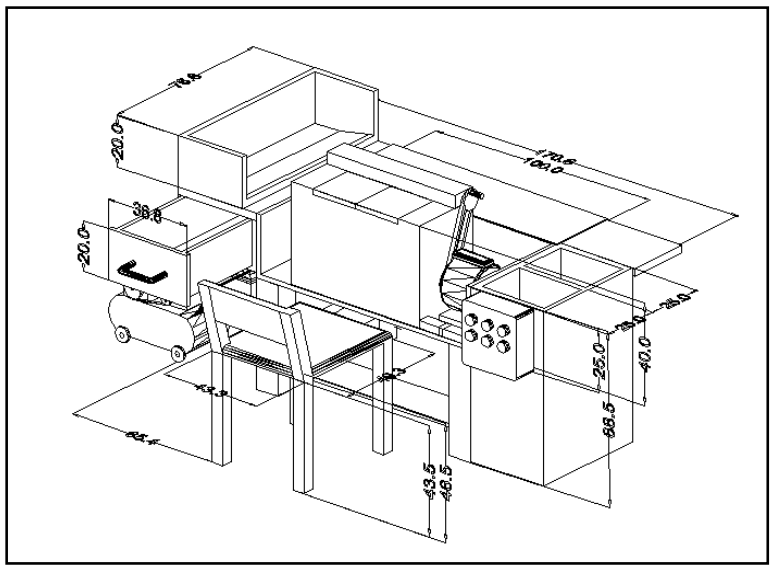

Fig. 8. Workstation design model.

(a). Space to put material that will be processed

There are two kind of box to put the raw materials; first, box with $12,500 \mathrm{~cm}^{3}$ volume and $20 \mathrm{~cm}$ depth and second, box with $42,812.5 \mathrm{~cm}^{3}$ and $68.5 \mathrm{~cm}$ depth. Materials which lenght is below $40 \mathrm{~cm}$ will go to the $20 \mathrm{~cm}$ depth box, while 68.5 box is used to store materals which length is more than 68.5. The location is determined based on operator convenience when picking up raw materials.

(b). Space to put half-finished product

Half-finished product volume is $320 \mathrm{~cm}^{3}$, while the storage box volume is $45.760 \mathrm{~cm}^{3}$. Thus, this box is sufficient for 143 piece of half-finished products in 5 piles. The amount of the stacks is determined based on the material strength and the range between the operator position and the box, so that the operator can easily reach the half-finished product.

(c). Space to put finished product.

The volume of finished product is $144 \mathrm{~cm}^{3}$, while the box volume is $36,800 \mathrm{~cm}^{3}$. Thus, this box is sufficient for 225 piece of finished products in 5 piles. The amount of the stacks is determined based on the material strength and the range between the operator position and the box, so that the operator can easily store the finished product.

(d). Panel

The length of the panel to control the fire is $75 \mathrm{~cm}$. This length is based on the side reach of the arm.

\subsection{New workstation standard time determination}

Table 3. Operator working time.

\begin{tabular}{cccccccccc}
\hline \multirow{2}{*}{ Operator } & \multicolumn{7}{c}{ Working Time } & $\sum X$ & $\bar{X}$ \\
\cline { 2 - 8 } & $\mathbf{1}$ & $\mathbf{2}$ & $\mathbf{3}$ & $\mathbf{4}$ & $\mathbf{5}$ & $\mathbf{6}$ & $\mathbf{7}$ & & \\
\hline 1 & 112 & 113 & 114 & 112 & 113 & 112 & 113 & 789 & 112.71 \\
\hline 2 & 114 & 113 & 112 & 113 & 112 & 114 & 113 & 791 & 113.00 \\
\hline 3 & 112 & 112 & 112 & 113 & 112 & 113 & 112 & 786 & 112.28 \\
\hline
\end{tabular}


After the calculation it is obtained standard time for the first operator 0.036 hours/piece, the second operator 0.037 hours/piece and the third operator 0.035 hours/piece. Thus, the approximate standard time required by the operator per souvenir on the new workstation is 0.036 hours/piece or 2.17 minutes/piece.

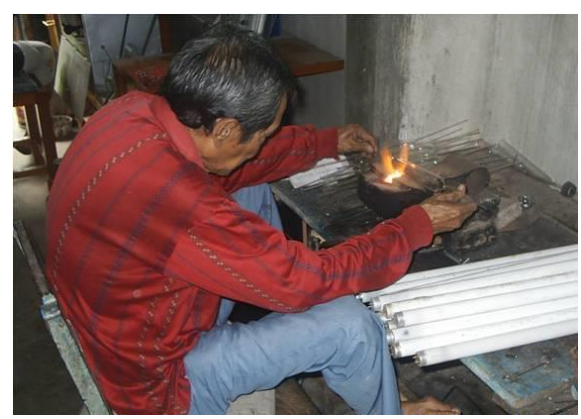

Fig. 9. Old workstation.

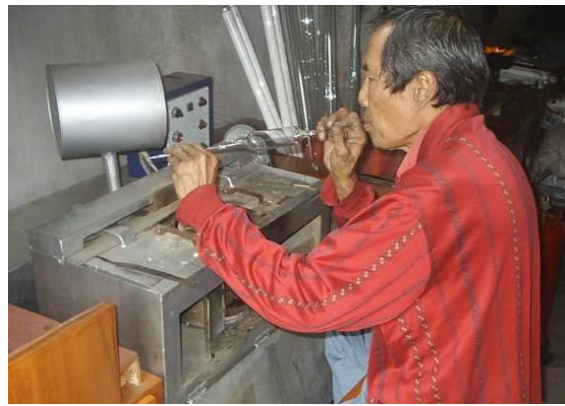

Fig. 10. New workstation.

Handicraft products produced by utilizing fluorescent lamp waste can contribute positively in the field of product design, environmental hygiene and improving people's welfare. MSEs in Randuagung Singosari Malang area can obtain abundant raw materials available from factory discharges in the area, thus spurred citizens who can not afford to become entrepreneurs.

With the new workstation, workers can make the process of making this handicraft product more comfortable, not tired, not much time is wasted and the resulting product is also more varied. With the many variations of handicraft products produced, the benefits not only for wedding souvenirs, but also can be used as home accessories, office or gift for someone.

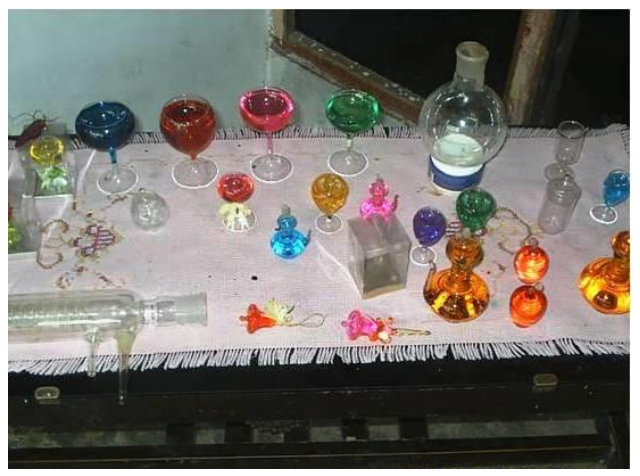

Fig. 11. Finished handicraft product.

\section{Conclusion}

The result of fluoescent lamp waste recycling tool design shows that the new workstation is more ergonomic because:

(1). The workbench has a reachable raw material storage hence the operator can reach it without leaving the seat.

(2). The workbench has plenty storage for half-finished and finished product hence the workbench is more practical and clean.

(3). It is eqquiped with a compressor which is connected with fuel tube. To add the air pressure the operator only need to open faucet without leaving his seat. 
(4). The workbench and seat are designed based on the anthropometry of the operator that work on the souvenir forming and combustion. The dimension is: table height 68.5 $\mathrm{cm}$, table length $170.6 \mathrm{~cm}$, table width $76.6 \mathrm{~cm}$, seat height $46.5 \mathrm{~cm}$, seat width 43.3 $\mathrm{cm}$, depth of the seat mats $49.3 \mathrm{~cm}$, and height of lumbar backrest $30 \mathrm{~cm}$.

(5). It can reduce allowance time, with the following comparison:

\begin{tabular}{ccc}
\hline Allowance & Before the design & After the design \\
\hline Recess & 20 minutes $(4.16 \%)$ & 5 minutes $(1.04 \%)$ \\
\hline
\end{tabular}

(6). The application of ergonomic workstation accelerate souvenir making process as follows:

\begin{tabular}{lc}
\hline \multicolumn{1}{c}{ Workstation } & Standard Time (minute/piece) \\
\hline Before the design & 2.58 \\
After the design & 2.17 \\
\hline
\end{tabular}

\section{Acknowledgment}

The author gratefully acknowledge the help of the following in connection with our research on Malang: the Malang Handcrafters Association (APKM), the University of Merdeka Malang, the Central Bureau of Statistics, Malang Public Library, and Bank Indonesia.

\section{References}

1. A. Suprapto, M. Rofieq, A. Poerwanto, Collaboration of SMK Mutu, Posdaya Kulbanda and LPPM University of Merdeka Malang in Sharing Skills. Journal ABDIMAS, 2, 1 (2017)

2. Constitution of the Republic of Indonesia No. 20 (2008).

3. E. Nurmianto, Ergonomics, Basic Concept and Its Application (Guna Widya, Surabaya, 1996).

4. I.B. Adnyana, Manuaba, Increased Productivity of Manufacture and Service Industries (Seminar and Panel Discussion Ergo-Design, Malang, 1999).

5. J. Croney, Anthropometry for Designers (BT Basford Ltd, London, 1987).

6. M. Rofieq, et al. Ergonomic Workstation Design on Souvenir Making Process at Randu Agung Singosari Malang Regency. (Unpublished, Paper presented at research of young lecturers, University of Merdeka Malang, 2008).

7. M. Rofieq, A. Poerwanto, H. Budiyanto, Product Packaging Design Training for MSME Crafts, Culinary and Posdaya. Journal ABDIMAS, 2, 2 (2017)

8. P. K. Suma'mur, Ergonomics for Work Productivity (CV. Haji Masagung, Jakarta, 1989).

9. S. Wignjosoebroto, Engineering Procedures and Work Measurement (Guna Widya, Surabaya, 1992).

10. UNESCO/ITC International Symposium on Crafts and the International Market: Trade and Customs Codification (Manila, Philippines, October 1997). 